McGill Journal of Education

Revue des sciences de l'éducation de McGill

\title{
Enacted Agency in a Cross-Border, Online Biliteracy Curriculum Making: Creativity and bilingual digital storytelling
} Action mise en oeuvre dans un curriculum de bilittératie,
transfrontalier en ligne : créativité et narration numérique
bilingue

\section{Zheng Zhang et Wanjing Li}

Volume 55, numéro 3, automne 2020

URI : https://id.erudit.org/iderudit/1083422ar

DOI : https://doi.org/10.7202/1083422ar

Aller au sommaire du numéro

\section{Éditeur(s)}

Faculty of Education, McGill University

\section{ISSN}

1916-0666 (numérique)

Découvrir la revue

\section{Citer cet article}

Zhang, Z. \& Li, W. (2020). Enacted Agency in a Cross-Border, Online Biliteracy Curriculum Making: Creativity and bilingual digital storytelling. McGill Journal of Education / Revue des sciences de l'éducation de McGill, 55(3), 550-567. https://doi.org/10.7202/1083422ar

\section{Résumé de l'article}

Cette recherche a examiné les potentiels de la création d'histoires numériques bilingues pour engager la créativité de 13 apprenants bilingues canadiens et chinois âgés de 11 à 15 ans. Les conclusions de cet article sont soutenues par six participants principaux et leur création d'histoires numériques. Informée par les multilittératies axées sur les actifs, les nouvelles connaissances médiatiques et le nouveau matérialisme, cette recherche a adopté une méthodologie de netnographie afin d'explorer les pratiques communautaires et sociomatérielles intégrées dans les intra-actions des espaces humains, matériels et virtuels de Seesaw et Skype. En s'appuyant sur les données de six étudiants cibles, les résultats décrivent comment les intra-actions entre les chercheurs, les enseignants, les étudiants, les matières et les espaces ont façonné les actes créatifs des participants. Cette recherche s'ajoute à la connaissance du développement et de l'application de pédagogies fondées sur le matériel qui soutiennent l'action mise en oeuvre parmi les enseignants, les étudiants, les matériaux et les espaces. (c) Faculty of Education, McGill University, 2021
Ce document est protégé par la loi sur le droit d'auteur. L'utilisation des services d'Érudit (y compris la reproduction) est assujettie à sa politique d'utilisation que vous pouvez consulter en ligne.

https://apropos.erudit.org/fr/usagers/politique-dutilisation/ 


\title{
ENACTED AGENCY IN A CROSS-BORDER, ONLINE BILITERACY CURRICULUM MAKING: CREATIVITY AND BILINGUAL DIGITAL STORYTELLING
}

\author{
ZHENG ZHANG \&WANJING LI Western University
}

\begin{abstract}
This research investigated potentials of bilingual digital story making to engage the creativity of 13 Canadian and Chinese biliteracy learners aged 11-15. Findings in this paper draw on six focal participants and their digital story creation. Informed by asset-oriented multiliteracies, new media literacies, and new materialism, this research adopted a netnography methodology to explore the communal and sociomaterial practices embedded in the intra-actions of human, matter, and virtual spaces of Seesaw and Skype. Drawing on data from six focal students, findings relate how intra-actions among researchers, teachers, students, matters, and spaces shaped participants' creative acts. This research adds to the knowledge of developing and applying material-informed pedagogies which attend to the enacted agency among teachers, students, materials, and spaces.
\end{abstract}

\section{ACTION MISE EN OEUVRE DANS UN CURRICULUM DE BILITTÉRATIE, TRANSFRONTALIER EN LIGNE : CRÉATIVITÉ ET NARRATION NUMÉRIQUE BILINGUE}

RÉSUMÉ. Cette recherche a examiné les potentiels de la création d'histoires numériques bilingues pour engager la créativité de 13 apprenants bilingues canadiens et chinois âgés de 11 à 15 ans. Les conclusions de cet article sont soutenues par six participants principaux et leur création d'histoires numériques. Informée par les multilittératies axées sur les actifs, les nouvelles connaissances médiatiques et le nouveau matérialisme, cette recherche a adopté une méthodologie de netnographie afin d'explorer les pratiques communautaires et sociomatérielles intégrées dans les intra-actions des espaces humains, matériels et virtuels de Seesaw et Skype. En s'appuyant sur les données de six étudiants cibles, les résultats décrivent comment les intraactions entre les chercheurs, les enseignants, les étudiants, les matières et les espaces ont façonné les actes créatifs des participants. Cette recherche s'ajoute à la connaissance du développement et de l'application de pédagogies fondées sur le matériel qui soutiennent l'action mise en œuvre parmi les enseignants, les étudiants, les matériaux et les espaces.

\footnotetext{
Social Sciences and Humanities Research Council's ${ }^{1}$ (SSHRC, 2018) The next generation of emerging global challenges identified 16 interrelated future global challenges. Many of the challenges emerge from technological innovations and request the "greatest need of attention from social science and humanities
} 
researchers" (p. I). UNESCO's (2017) working document of "E2030: Education and Skills for the 21st Century" accentuates the multiple facets of lifelong learning to nurture responsible and competent individuals through 21st century skill development, global citizenship education, digital literacy, and sustainable development education. Academic literature also calls for ethical, transformative literacy pedagogies to nurture younger generations with the skills and competences to come up with creative solutions to the pressing challenges in the 21st century (e.g., Mirra et al., 2018). This SSHRC-funded study explores a cross-border, online biliteracy curriculum. It is a timely response to Canada's two major future challenge areas: namely, using emerging technologies to benefit Canadians, and generating knowledge for Canada to thrive in the globalized world.

Emergent literature on bilingual education in Canada has discussed the use of transformative multiliteracies pedagogies to leverage bilingual learners' assets of meaning-making in different languages, modes, and technologies (e.g., Cummins et al., 2015). However, there is a scarcity of online, cross-border biliteracy programs in Canada that harness biliteracy learners' assets for creative meaning-making in both English and their heritage language of Mandarin. Collaborating with Mandarin and English language teachers and students, the research team actualized a cross-border, online biliteracy curriculum that connected six Canadian biliteracy learners (i.e., learners in Canada who speak the heritage language of Mandarin but are more fluent in English) and seven Chinese biliteracy learners (i.e., learners in China who are fluent in Mandarin but learning English as a foreign language). The participants were 11-15 years old. Our study built social networking spaces through Seesaw and Skype for these learners to develop biliteracy and new media literacies skills.

The cross-border, online biliteracy curriculum making recruited joint engagement between academics, Mandarin and English teachers, and biliteracy learners from Canada and China. Existent literature on actualizing emergent curriculum in various early childhood education contexts accentuates students as agentive protagonists of curriculum making (e.g., Tal, 2014; Thomas, 2008; Verwys, 2007). Studies also show the Reggio Emilia model of early childhood education as aptly representing the emergent curricular paradigm (Barnett \& Halls, 2008; Boyd \& Bath, 2017; Fantozzi et al., 2013; Hesterman, 2011; Heydon \& Wang, 2006; Mills, 2013; Murris, 2016; Stegelin, 2003). However, few studies on the emergent curriculum attend to the agency of materials in digital story creation, and the impacts of human-matter intra-actions on creative meaning-making. To respond to this gap, the paper asked:

1. What are teachers', students', and matter's roles as creative entities to enact the emergent cross-border, online biliteracy curriculum? 
2. What are the implications of cross-border, online biliteracy projects for new pathways of creative meaning-making?

\section{THEORETICAL FRAMEWORK}

The study was undergirded by asset-oriented multiliteracies and new media literacies. Acknowledging the sociomaterial turn in literacy research (e.g., Kuby \& Rowsell, 2017; Smythe et al., 2017; Toohey et al., 2015), we applied critical re-reading of these theoretical lenses in this material-informed study.

\section{Asset-oriented multiliteracies and our critical re-reading}

One theoretical underpinning of this biliteracy project was multiliteracies (The New London Group, 1996). Multiliteracies proposes an expanded notion of literacy shaped by rapid social, cultural, and technological changes. Multiliteracies pedagogy responds to the growing cultural and linguistic multiplicity and diversity that is intensified by globalization activities such as immigration, multiculturalism, and global integration (Cope \& Kalantzis, 2000; Kalantzis \& Cope, 2008). Expanding the dimensions of literacy and literacy education, multiliteracies attempts to provide "holistic" (Cope \& Kalantzis, 2009, p. 167) literacy pedagogies to engage language differences, multiple sign systems, diverse communication channels, and various domains of literacy practices (e.g., those at home, in school, and across various disciplines).

Our cross-border, online biliteracy project was in line with the multiliteracies pedagogies that celebrate "the many ways that people write, speak, or read themselves into the world" (Moje \& Luke, 2009, p. 434). We also designed our project to capitalize on biliteracy learners' funds of knowledge (González et al., 2005) — that is, to develop their creative ways of representation based on their funds of knowledge in both English and Mandarin, the associated cultures, and multiple semiotic resources. However, we were also aware of the constraints of the multiliteracies lens in framing human and non-human agency in creative meaning-making. Leander and Boldt (2012) critiqued that multiliteracies overemphasize human agency in utilizing multilingual and multimodal materials as resources. Portraying materials only as resources casts aside the agency of non-human animals and matter. In this project, we attended to enacted agency that is continuously produced through the intraactions between meaning makers and materials (Kuby et al., 2017); we interrogated the binary in human and/or nonhuman agency and define agency as "an enactment between humans and nonhumans" (p. 357). Enacted agency is produced in the entanglement of meaning makers and materials, similar to the case of turtles crawling on the beach. Without the assemblage of animal agency, sand and rock on the beach, and the force of friction, turtles could not even move at the speed of turtles. 
Barad's (2007) agential realism accentuates the inextricable ties between reality and language, matter and meaning. As Barad contended, "the 'distinct agencies' are only distinct in a relational, not an absolute, sense, that is, agencies are only distinct in relation to their mutual entanglement; they don't exist as individual elements" (p. 33). Instead of individual objects with inherent "boundaries and properties," Barad's relational ontology foregrounds phenomena as the primary ontological unit and perceives phenomena as the "ontological inseparability of intra-acting 'agencies'” (p. 333). Likewise, creative meaning-making practices do not center around human agency but involve coproduction processes of all participating human and non-human entities. Without the force that is enacted by multiple materials and media in their intra-actions with humans, creative meaning productions would not be possible. Creative meaning-making takes place because matter and humans are in mutual relationality and influence one another. The removal of human from the ontological centre of meaning-making welcomes ethical responsiveness to and reciprocal relationship-building with non-human animals, matter, and spaces (Murris, 2016).

In this paper, we explore teachers', students', and matter's roles as creative entities to enact the cross-border, online biliteracy curriculum and look at how enacted agency emerged in the entanglement and assemblage of meaning makers and materials. Our focus in the material-informed research was on the agential performativity of humans, materials, and the virtual and physical contexts as well as the transformative potentials of their relational encounters in creating new forms of meaning.

\section{New media literacies and our critical re-reading}

Under the new media literacies framework, Jenkins (2009) highlighted the focus shift from "individual expression" to "community involvement" in meaningmaking via new media and technologies (p. xiii). Jenkins argued that youth are actively involved in participatory cultures and develop their new literacies skills through online participation and collaboration. Likewise, our cross-border, online biliteracy project created collaborative virtual spaces through Seesaw (an educational app for student-driven digital portfolios) and Skype for both synchronous and asynchronous intra-actions. We intended to provide strong support and mentorship for Canadian and Chinese biliteracy learners, share new creative forms, engage divergent perspectives of their global peers, and facilitate collaborative problem-solving to develop creative digital stories.

In the process of enacting the cross-border, online biliteracy curriculum, we started to see new media literacies' constraining interpretative power because it over-rationalizes biliteracy learners' participation and collaboration in the online community. Informed by the emerging literacy studies on new materialism and posthumanism (e.g., Justice, 2016; Kuby \& Rowsell, 2017; Kuby et al., 2019; Leander \& Boldt, 2012), our gazes turned to focus on how 
humans, diverse forms of matter, and physical and virtual spaces worked relationally to bring the digital stories to life. We also looked at whether enhancing biliteracy learners' connections with humans, materials, and spaces across linguistic, cultural, and geographical boundaries could facilitate their creative meaning-making in two languages and multiple modes and media.

\section{PROJECT DESIGN}

The research objectives were achieved through the strengths of a netnography methodology that is suitable for investigating cross-border, online biliteracy curricula. Netnography is an emerging methodology designed to study interactions on social media platforms (Kozinets, 2010a). Netnography helped the research team explore the communal and sociomaterial practices that are embedded in the intra-actions of human, matter, and virtual spaces. We used netnography to examine online aspects of biliteracy learners' cross-border interchanges and portfolios containing their meaning-making artifacts. The purpose of using this method was to show "how knowledge creation and learning occur through a reflective 'virtual re-experiencing' discourse among the members of innovative online communities" (Kozinets, 2010a, p. 2).

The project spanned from February 13 to June 6, 2019 on Seesaw, a social network site, and through synchronous interactions on Skype. In this paper, we draw on the following netnography data sources to shed light on the emergent nature of the cross-border, online biliteracy curriculum and biliteracy learners' creative meaning-making: 1) students' shared digital storytelling portfolios and online interactions on Seesaw; 2) transcribed video data of synchronous interactions on Skype; and 3) interviews with students either on Skype or onsite about their perspectives of the impacts on the cross-border, online biliteracy learning experience.

Participants were 11-15 years old and included six Canadian and seven Chinese biliteracy learners. In this paper, we draw on data about six focal participants and their digital story creation (see Table 1 for the focal participant profile).

Amelia attended an international school in China and was fluent in both English and Mandarin. All the five focal participants from Canada came from immigrant families with Chinese descent. They lived in two cities in Eastern Canada and did not know one another before the project. An offline face-toface meeting was arranged by the research team for Aaron and Adam because Aaron asked for help with stop motion animation making. 
TABLE I. Focal Participant Profile

\begin{tabular}{llll}
\hline Pseudonyms & Age & Country of Origin & Self-Identified Mother Tongue \\
\hline Amelia & 11 & China & Mandarin \\
Chloe & 13 & Canada & English /French \\
Jenny & 14 & Canada & Mandarin \\
Aaron & 11 & Canada & English \\
Adam & 15 & Canada & Mandarin \\
Kenna & 13 & Canada & Mandarin \\
\hline
\end{tabular}

Our data analysis focused on "content" (e.g., students' meaning-making with creative tools that were documented on the educational app Seesaw) and "context" (e.g., the features of Seesaw and Skype that enabled social networking opportunities with an authentic global audience) (Kozinets, 2010b, p. 4). Data analysis started when the cross-border, biliteracy curriculum began to unfold based on the continuous intra-actions between researchers, English and Mandarin teachers, biliteracy learners, and more-than-human entities. Instead of deductively reducing data to abstract codes and categories based on theoretical lenses, we remained open to emerging themes throughout data collection. We allowed the emergent data to lead us to the next stage of bilingual digital story making. For example, students played a major role in deciding topics that they were interested in exploring for their digital storytelling when they shared initial ideas on Seesaw and posted their storyboards. The relational encounters of the research team, language teachers, students in China and Canada, materials, and spaces continuously transformed the enactment of the cross-border, online biliteracy curriculum about what to learn, how, and when. We adopted a reflexive, iterative approach to data analysis that focused on "visiting and revisiting the data and connecting them with emerging insights, progressively leading to refined focus and understanding" (Srivastava \& Hopwood, 2009, p. 77). The iteration of data analysis attended to the evolving intra-actions between the research team, Mandarin and English teachers, biliteracy students, and other non-human entities (e.g., gadgets, apps, LEGO, cardboards, and physical and virtual spaces).

\section{FINDINGS ILLUSTRATED THROUGH BILITERACY LEARNERS' CREATIVE DIGITAL STORY-MAKING}

In this section, we present the findings through examples of six focal biliteracy learners' creative digital storytelling. The examples will exhibit the emergent nature of their creative meaning-making and shed light on how the agentic 
assemblages of diverse elements (researchers, teachers, students, matter, and spaces) were "constantly intra-acting, never stable, never the same" (Lather \& St. Pierre, 2013, p. 630) to shape biliteracy learners' creative acts. The study has generated new knowledge on how a research team, language teachers, and biliteracy learners can collaboratively develop and enact a cross-border, online curriculum to espouse biliteracy and new media literacies skills.

The focal participants commented on the affordances of emergent curriculum decision making that embraced students' agency. As Aaron from Canada said, by allowing students to shoot and write about something that they like, students "would like to keep writing it or keep working on it." Wiebe and Caseley Smith (2016) contended that preparing students for prescribed curriculum outcomes constrains creativity in teaching. Accentuating teachers' artistic creation and agency, they argued that explicit instruction does not "help students achieve the necessary literacies for today's digital world" (p. 1167). Prior to and throughout data collection, graduate research assistants and language teachers conferred and negotiated the differences between logocentric literacy teaching and material-informed literacy education approaches. Biliteracy learners therefore did not learn a discrete set of predicable language patterns; instead, they received substantial peer and teacher support for their individual biliteracy learning purposes. Neither the research team nor the participants could predict what they would have created at the beginning of the project. Their experimentation with traditional and digital technologies transformed their practices in digital story making. In the post-research interviews, all six focal students commended the enhanced creativity in their meaning-making both in Mandarin and English.

Both interview data and data on Skype synchronous intra-actions show that the focal participants reported enhanced engagement in the bilingual digital story creation because meaning-making was "profoundly relational" (Howard et al., 2018, p. 857). The learners' ongoing storytelling unfolded the potential of such a cross-border, biliteracy project to enable biliteracy learners' continuous development in their posthuman ethico-onto-epistemology; that is, the ethical knowing / becoming / doing of literacies through virtual connections among learners who are geographically separated. As Newfield and Bozalek (2019) argued, literacy cannot be taught autonomously, unrelated to time, space, and matter. Students' online intra-actions and the postinterview data demonstrate their desire to be connected globally while learning new technologies for meaning-making. In the last Skype meetings, groups of participants shared their self-reflection about their story creation experience and offered suggestions and feedback to their peers' digital stories. Through self-reflection, comments, and suggestions, participants exhibited their critical viewing skills, including their critical thoughts about peers' modal choices, reasons for alternative modal choices, connections to personal strengths and interests, perceptions of audience engagement with the artifacts, 
and challenges encountered when creating the digital story. In the postresearch interview, Adam from Canada reported how cross-border collaboration helped shape his creativity in the digital storytelling:

A lot of the peers in China would give a lot of suggestions that I haven't considered before, and I think that really helps with my creativity and in the future, I could look a concept in broader ways.

As the interview data show, all the focal biliteracy learners discussed how intraactions through reflection and feedback provision nurtured their sense of community building and awareness of a global audience.

Storyboarding in visual texts was a powerful approach that encouraged biliteracy learners to experiment with digital materials while they polished plot design ideas. Constantly intra-acting with materials, Adobe Illustrator, and teachers and peers from both Canada and China, Adam used Seesaw to document how his storyline evolved from his first-version storyboard to his second-version storyboard, bilingual scripts, and animation making through Adobe Illustrator.

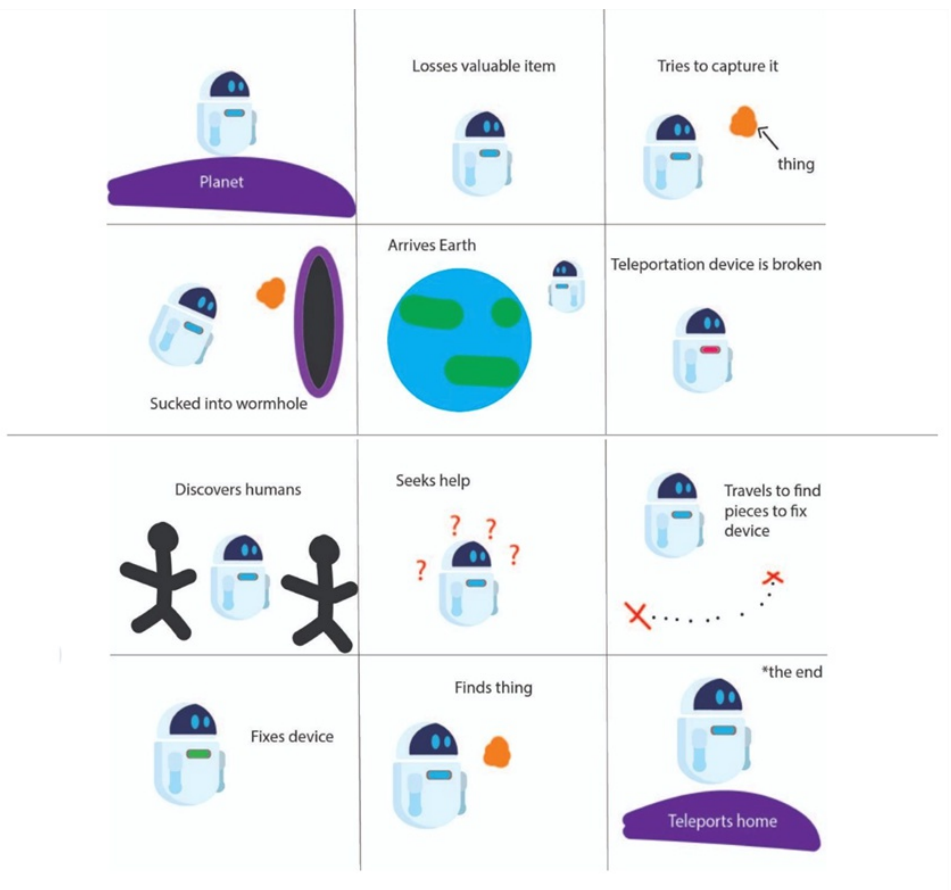

FIGURE I. Adam's First-Version Storyboard 


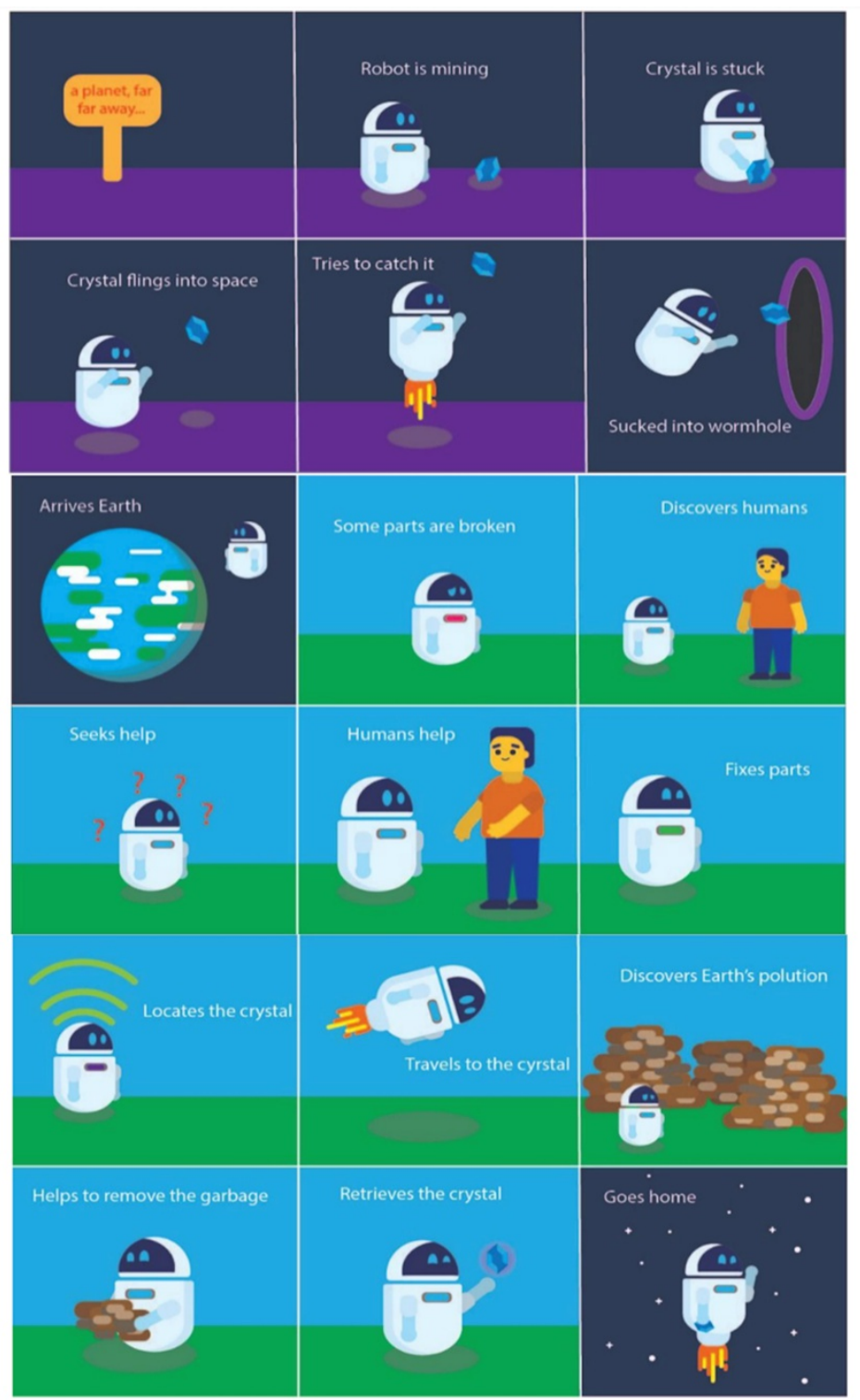

\section{FIGURE 2.Adam's Second-Version Storyboard}

Figure 1 and Figure 2 show the evolvement of Adam's storyline. His entanglement with the apps, the plot, and his own life and drawing experience helped develop his understanding of the affordances and constraints of the apps. He also attributed the storyline development to the relationality with and constructive feedback from his global peers and language teachers (see Figure 3 for his final story). 


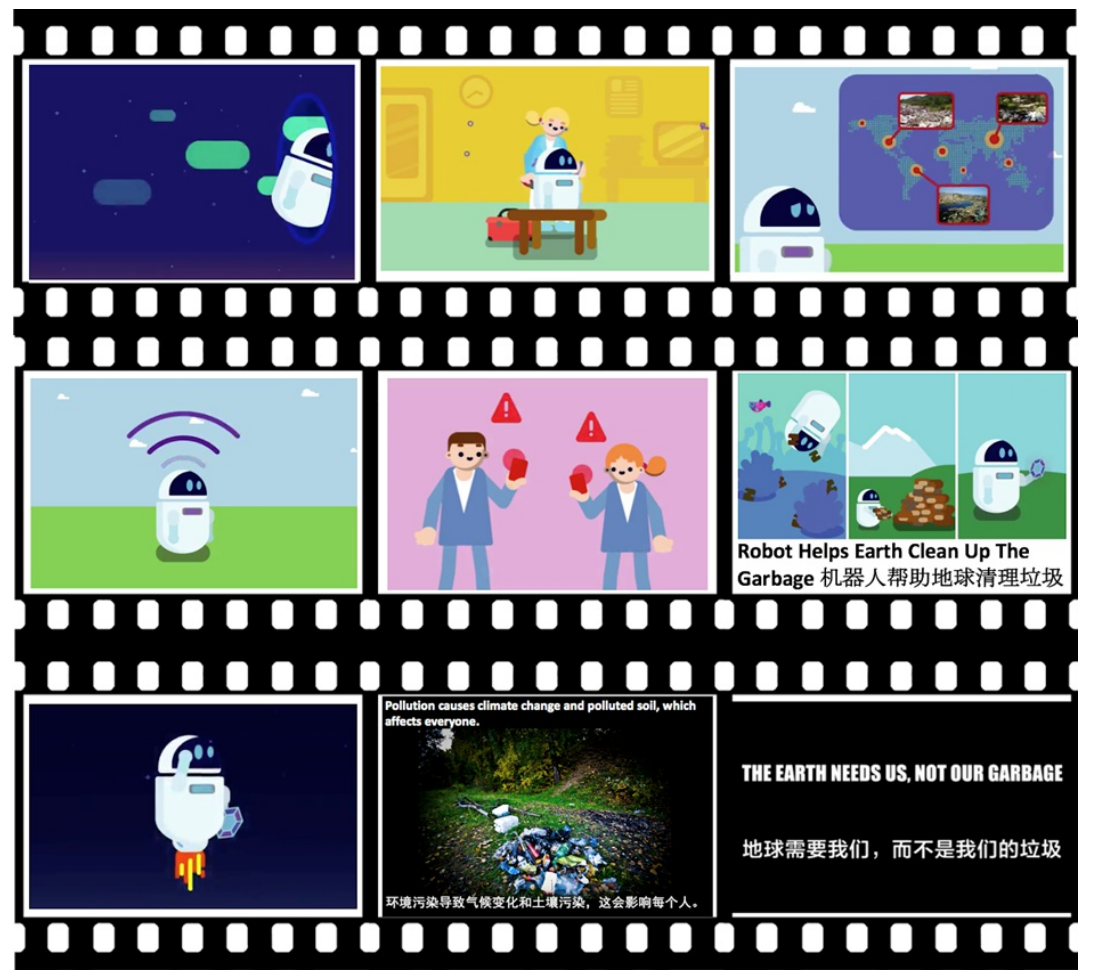

FIGURE 3. Screenshots of Major Scenes of Adam's Final Digital Story

Similar to Wiebe and Caseley Smith's (2016) findings, biliteracy learners also showed sustained engagement in revising their bilingual scripts. Amelia, Kenna, and Chloe named themselves the Cat Lords and their "collaborative play-creating" emerged through online sharing and discussion (Carter et al., 2011, p. 20). The collaborative meaning-making also enabled divergent perspectives and new ways of constructing meaning to emerge (see Figure 4).

The Cat Lords' (Figure 4) new knowledge about coordinating sketching, line art, and coloring with Flipaclip and collaborating with global peers was "always emerging and evolving" (Carter et al., 2011, p. 19). Chloe commented on the force of divergent thinking in shaping her experience in the project:

I think there was really strong support because there were, like... everyone was really open to, like, open to all types of ideas. I guess it just made us feel more accepted because even though we maybe have [...] really different ideas from other people, like um... our teachers and [...] our friends and my... and my classmates are still, like, supporting us during the making of our project.

Unique bodily intra-actions and communicative relationships were enacted by the virtual spaces in Seesaw and Skype and effected impacts upon participants' creative storytelling. 


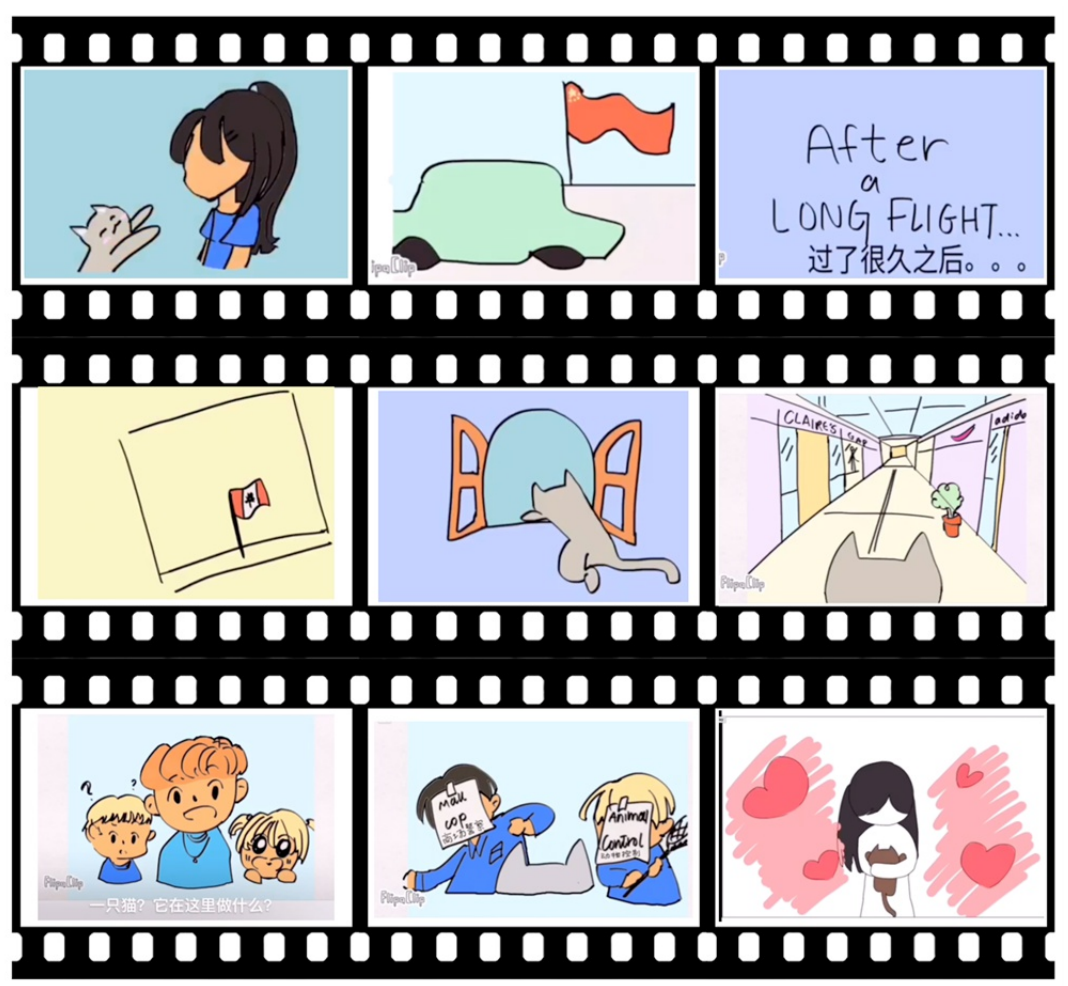

FIGURE 4. Screenshots of Major Scenes of The Cat Lords' Final Digital Story

Online intra-actions and interview data show that creative biliteracy meaningmaking emerged while humans and matter worked relationally to bring their digital stories to life. In the post-research interviews, the focal participants shared their appreciation of the opportunities to tap into the "synaesthetic potentials" in their "transformative, creative actions" with multimodal materials and artifacts (Kress, 1997, p. 27). The focal participants' digital stories exhibit the creative affordances of orchestrating multiple ways of meaning-making compared to mono-mode texts. Jenny's Chinese shadow puppet movie exemplifies the force of ensembled modes that helped reproduce the artistic features of the original Chinese classic poem "Sunny Sand and Autumn Thoughts" (see Figure 5).

We observed how Jenny experimented with the materials to make sure the crow flies, the horse gallops, the sun goes down behind the hill, and the people walk on the bridge in the shadow puppet movie. In the edited movie, the traditional Chinese zither music plays as the background music, intertwined with the crow growling, scattered kids' giggling, river gurgling, and Jenny's oral interpretation of the Chinese classic poem in Mandarin. Jenny 


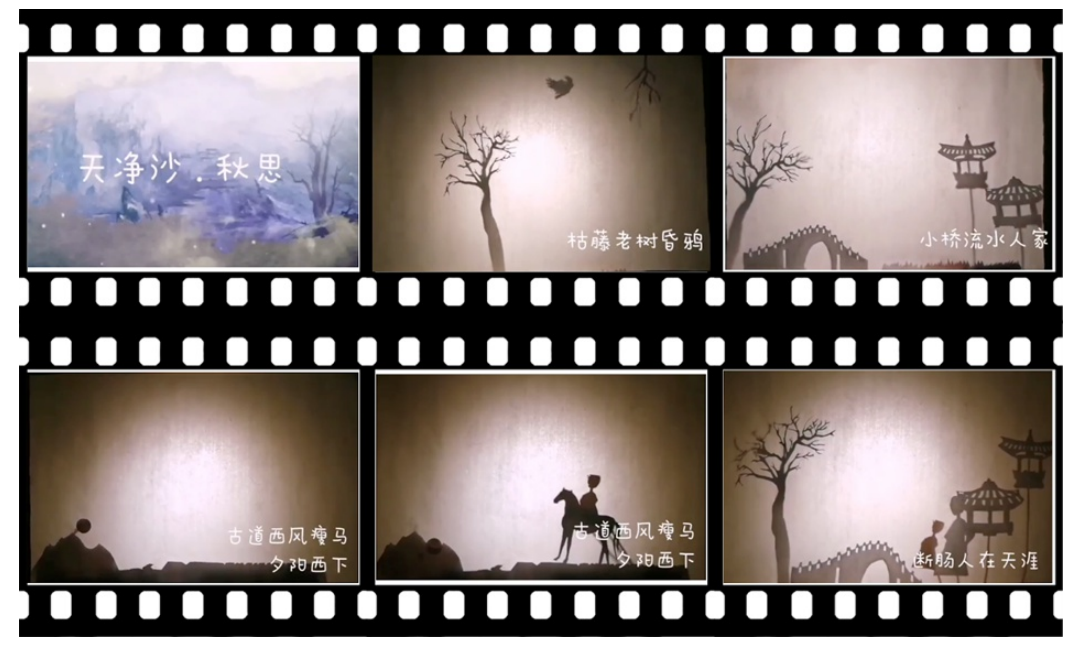

FIGURE 5. Screenshots of Major Scenes of Jenny's Final Digital Story

also moved the cut-out figures and the light source to create various effects indicating dawn, bright daylight, and sunset. The sensory entanglement of human and more-than-human entities in her digital story reconfigures the world that is conveyed by the well-known Chinese classic poem and enables the original gloomy and desolate loneliness to emerge.

Wiebe and Caseley Smith (2016) argued that abstract text-only representations could become concrete and "visible through the materiality of film" (p. 1172). Likewise, Chloe commented on how drawing and animation brought the Cat Lords' co-created bilingual scripts to life and how their subjectivities breathed life into the creation:

I think the animation that we did kind of expresses, like, ourselves, because we kind of put our personalities in the drawings, like, the way we draw is [...] related to us in some way but as, like, the kind of artist. I think that the way that everyone draws is, like, what type of person they are. For example, if you're [...] a really sad person or anything like that, then you will only draw with [...] a lot of black scribbles and whatever. If you're a really lively person, then you will probably draw a bunch of rainbows everywhere. So I think that's the way of expressing ourselves in another way than texting.

Throughout the research, researchers and language teachers also attended to how learners' material-discursive intra-actions shaped the flow of the online biliteracy curriculum. Biliteracy learners' creativity shone through their intraactions with materials. Figure 6 contains snapshots of Aaron's LEGO stopmotion animation.

When asked whether the project enhanced his creativity in his digital storytelling, Aaron's answer was brief: "Yes... Like using LEGO to shoot the movie". It was Aaron's first-time creating LEGO stop-motion animation. 


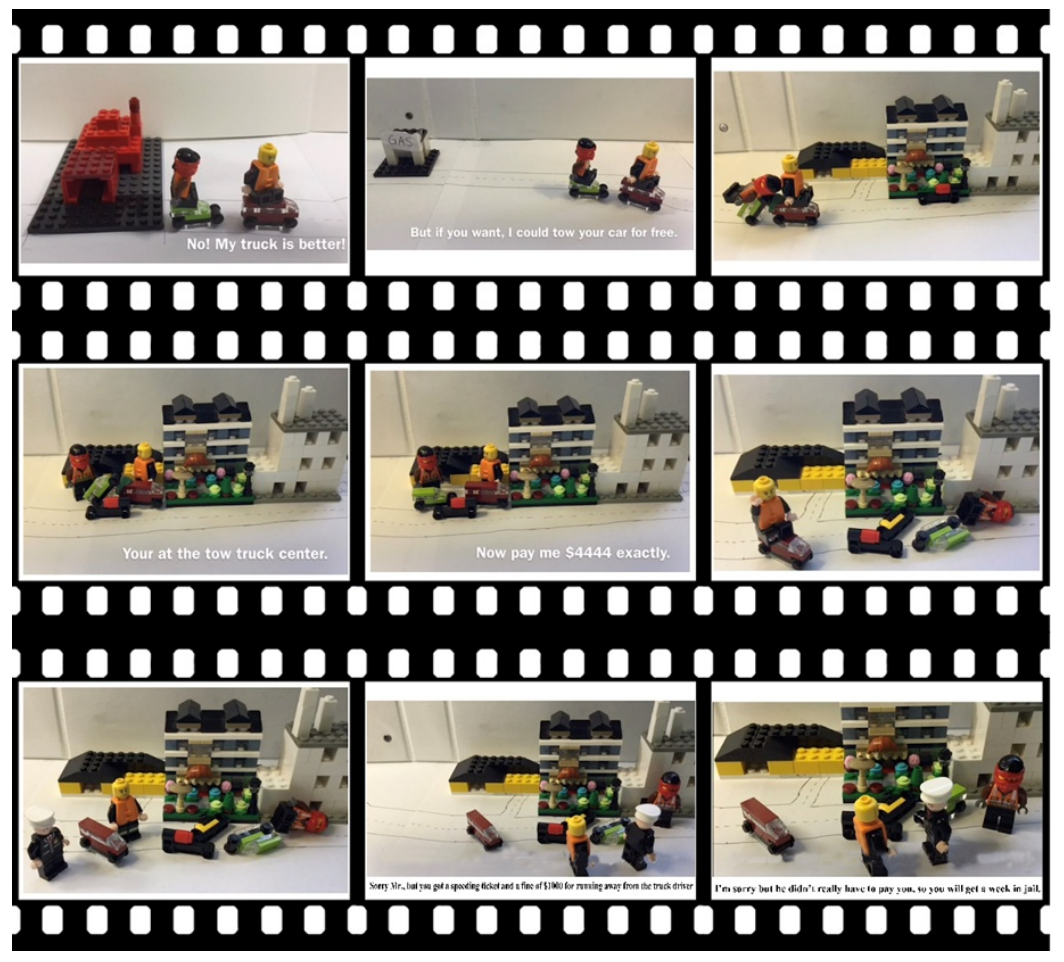

FIGURE 6. Screenshots of Major Scenes of Aaron's Final Digital Story

Similar to Wiebe and Caseley Smith's (2016) argument that "an artist's way of thinking and being are the ways curriculum work lives in the relational, messy world" (p. 1169), the process of Aaron's creation of LEGO stop-motion animation was messy and (dis)continuous. Aaron's Scene One footage looked jumpy. After viewing it, Adam helped Aaron to shoot and edit stop-motion footages in a peer-support, face-to-face meeting including Adam, Aaron, and language teachers. Adam and Aaron set up backgrounds for individual scenes, and Aaron took pictures until there were sufficient stop-motion pictures for a specific scene. When Aaron started editing the movie, Adam gave suggestions to Aaron regarding the length of footages, transition of scenes, and how to avoid jumpy footage. During this meeting, LEGOs, cardboards, the camera, and movie-editing apps entangled with Aaron and Adam and impacted their verbal discussions and bodily intra-actions.

Despite their tight school schedule, all six focal participants persisted in creating the digital stories after school. When asked why, Adam said, "This is something that I am very interested in, but normally parents would not allow me to do in outside-of-school life". Moje and Luke (2009) argued that literacyand-identities research should move beyond "simple admiration for or celebration of the many ways that people write, speak, or read themselves into 
the world" (p. 434). They recommended further research that links identity and learning in multiple domains. Findings of the six focal participants' digital story creation relate that this cross-border, online biliteracy curriculum engaged biliteracy learners in a spectrum of literacies through capitalizing on learners' funds of knowledge, namely, their peripheral linguistic, cultural, and semiotic knowledge. The findings also show how biliteracy learners' relationality with matter and humans helped bring their subjectivities to presence.

\section{CONCLUSION AND SIGNIFICANCE}

In this study, biliteracy learners' relational knowing / becoming / doing literacies left material traces in the virtual spaces and learners' situated worlds, such as the transformed worlds around them, the enhanced relationality with global peers and traditional / digital materials, and their transformed practices in meaning-making. In turn, the cross-border, biliteracy research prompted the researchers and language teachers to engage ethical meaning-making via multimodality, relation-building, and interdisciplinary exploration. This research offers a counter-narrative to the neoliberal application of new media and digital literacies in certain schooling systems; for example, the inclusion of digital tasks in standardized curriculum and assessment (e.g., PISA testing), which might result in "normalizing, controlling what officially counts as digital creativity, critique, and innovation" (Garcia et al., 2018, p. 75).

The sociomaterial turn in literacy education and research has potential to help reconfigure new ways of representation and ways of learning and teaching literacies (Kuby et al., 2017). Though illuminated by multiliteracies in our prior and current projects (e.g., Zhang, 2015; Zhang \& Heydon, 2014; Zhang et al., 2020), we are in line with the current critiques of multiliteracies as an advocacy for transformative and inclusive pedagogies (e.g., Jacobs, 2014; Leander \& Boldt, 2012; Rowsell \& Burgess, 2017). Our findings refer to the importance of literacy researchers' and educators' reconfiguration of the concept of design: the artifacts and digital stories presented in the paper reveal biliteracy learners' "spontaneous, random, and unexpected" creative meaningmaking (Jacobs, 2014, p. 272). Multiliteracies pedagogy portrays both teachers and learners as agentive in meaning-making (e.g., Kalantzis \& Cope, 2010; The New London Group, 1996). The findings refer to the possibilities offered by material-informed pedagogies which attend to the enacted agency that emerged between teachers, students, materials, and spaces — specifically the enacted agency of materials and cross-border virtual spaces in shaping creative literacy practices. These findings also allude to the shifting nature of 21st century biliteracy learners' meaning-making which is more variegated than the original call for multiliteracies back in 1996, as Rowell and Burgess (2017) exemplified. In the research process, graduate research assistants and language teachers appraised opportunities to learn with and from biliteracy learners 
about their creative intra-actions with traditional and digital materials. In contrast to top-down professional training that is mono-mode and print-based (Cloonan, 2010), meaningful professional learning is needed through which literacy educators, learners, and matter intra-act to create meaning. To nurture 21st century meaning-makers as "collaborative," "innovative," and "creative risk-takers" (Kalantzis \& Cope, 2012, p. 7), literacy educators need opportunities to engage in experiential professional learning likewise.

One key challenge we encountered in analyzing data in material-informed research was researchers' tendency to "interpret our observation [of meaningmakers'] behaviour [and] hasten to introduce a representational system to stand in for embodied materialities" (Hackett \& Somerville, 2017, p. 377). It required researchers' constant awareness to decenter the human in the various data sources that unfold creative meanings. Meaningful intra-actions with various traditional and digital materials and the cross-border virtual spaces enabled students' sustained engagement in creative meaning-making beyond classroom settings. Educators need sensibilities to attend to how young meaning-makers are, as Hackett and Somerville (2017) state, "coordinating their actions" among more-than-human, and equally important, how the more-than-human entities are "coordinating the actions" (p. 386) of the humans - therefore, to consider the "role of bodies, objects, and places" in ethical, creative meaning-making processes (p. 387). Future research on crossborder biliteracy education should also create spaces and incorporate elements that facilitate learners' instantaneous feedback to one another, either online or offline.

\section{NOTES}

1. Social Sciences and Humanities Research Council of Canada (SSHRC) is a Canadian federal research-funding agency that supports research and training in the humanities and social sciences.

\section{REFERENCES}

Barnett, V., \& Halls, D. (2008). Wire bicycles: A journey with Galimoto. In C. A. Wien (Ed.), Emergent curriculum in the primary classroom: Interpreting the Reggio Emilia approach in school (pp. 52-63). Teachers College Press.

Barad, K. (2007). Meeting the universe halfway: Quantum physics and the entanglement of matter and meaning. Duke University Press.

Boyd, D., \& Bath, C. (2017). Capturing student perspectives through a "Reggio" lens. International Journal of Teaching and Learning in Higher Education, 29(2), 192-200.

Carter, M., Belliveau, G., Irwin, R. L., \& Beare, D. (2011). A/r/tography as pedagogy: A promise without guarantee. Canadian Review of Art Education, 38(1), 17-32.

Cloonan, A. (2010). Multiliteracies, multimodality and teacher professional learning. Common Ground.

Cope, B., \& Kalantzis, M. (2000). Introduction: Multiliteracies: The beginnings of an idea. In B. Cope \& M. Kalantzis (Eds.), Multiliteracies: Literacy learning and the design of social futures (pp. 3-8). Routledge. 
Cope, B., \& Kalantzis, M. (2009). Multiliteracies: New literacies, new learning. Pedagogies: An International Journal, 4(3), 164-195.

Cummins, J., Hu, S., Markus, P., \& Montero, M. K. (2015). Identity texts and academic achievement: Connecting the dots in multilingual school contexts. TESOL Quarterly, 49(3), 555-581.

Fantozzi, V. B., Cottino, E., \& Gennarelli, C. (2013). Mapping their place: Preschoolers explore space, place, and literacy. Social Studies and the Young Learner, 26(1), 5-10.

Garcia, A., Luke, A., \& Seglem, R. (2018). Looking at the next 20 years of multiliteracies: A discussion with Allan Luke. Theory into Practice, 57(1), 72-78.

González, N., Moll, L., \& Amanti, C. (2005). Introduction: Theorizing practices. In C. González, L. Moll, \& C. Amanti (Eds.), Funds of knowledge: Theorizing practices in households, communities, and classrooms (pp. 1-28). Lawrence Erlbaum Associates.

Hackett, A., \& Somerville, M. (2017). Posthuman literacies: Young children moving in time, place and more-than-human worlds. Journal of Early Literacy Research, 17(3), 374-391.

Hesterman, S. (2011). Extending Reggio Emilia principles in the middle school context: A western Australian case study. Educational Practice and Theory, 33(1), 73-91.

Heydon, R. M., \& Wang, P. (2006). Curricular ethics in early childhood education programming: A challenge to the Ontario kindergarten program. McGill Journal of Education, 41(3), 29-46.

Howard, P., Becker, C., Wiebe, S., Carter, M., Gouzouasis, P., McLarnon, M., Richardson, P., Ricketts, K., \& Shuman, L. (2018). Creativity and pedagogical innovation: Exploring teachers' experiences of risk-taking. Journal of Curriculum Studies, 50(6), 850-864.

Jacobs, G. E. (2014). Reimagining multiliteracies: A response to Leander and Boldt. Journal of Adolescent $\mathcal{E}$ Adult Literacy, 57(4), 270-273.

Jenkins, H. (2009). Confronting the challenges of participatory culture: Media education for the 21st century. MIT Press.

Justice, S. (2016). Learning to teach in the digital age: New materialities and maker paradigms in schools. Peter Lang Publishing, Inc.

Kalantzis, M., \& Cope, B. (2008). Language education and multiliteracies. In T. May \& N. H. Hornberger (Vol. Ed.), Encyclopedia of language and education: Vol. 1. Language policy and political issues in education (pp. 195-212). Springer.

Kalantzis, M., \& Cope, B. (2010). The teacher as designer: Pedagogy in the new media age. ELearning and Digital Media, 7(3), 200-222. doi:10.2304/elea.2010.7.3.200.

Kalantzis, M., \& Cope, B. (2012). Literacies. Cambridge University Press.

Kress, G. R. (1997). Before writing: Rethinking the paths to literacy. Routledge.

Kozinets, R. V. (2010a). Netnography: Doing ethnographic research online. Sage Publications.

Kozinets, R. (2010b, March). Netnography, the marketer's secret weapon: How social media understanding drives innovation.

Kuby, C. R., \& Rowsell, J. (2017). Early literacy and the posthuman: Pedagogies and methodologies. Journal of Early Literacy Research, 17(3), 285-296.

Kuby, C.R., Rucker, T.G., \& Darolia, L.H. (2017). Persistence(ing): Posthuman agency in a writers' studio. Journal of Early Literacy Research, 17(3), 353-373.

Kuby, C.R., Spector, K., \& Thiel, J.J. (2019). Cuts too small: An introduction. In C.R. Kuby, K. Spector, \& J.J. Thiel (Eds.), Posthumanism and literacy education: Knowing/Becoming/Doing literacies (pp. 1-17). Routledge.

Lather, P., \& St. Pierre, E. A. (2013). Post-qualitative research. International Journal of Qualitative Studies in Education, 26(6), 629-633.

Leander, K., \& Boldt, G. (2012). Rereading "a pedagogy of multiliteracies": Bodies, texts, and emergence. Journal of Literacy Research, 45(1), 22-46. 
Mills, D. N. (2013). A qualitative study: Integrating art and science in the environment (Publication No. ED552989) [Doctoral dissertation, Wayne State University]. ERIC.

Mirra, N., Morrell, E., \& Filipiak, D. (2018). From digital consumption to digital invention: Toward a new critical theory and practice of multiliteracies. Theory Into Practice, 57(1), 12-19.

Moje, E. B., \& Luke, A. (2009). Literacy and identity: Examining the metaphors in history and contemporary research. Reading Research Quarterly, 44(4), 415-437.

Murris, K. (2016). The posthuman child: Educational transformation through philosophy with picturebooks. Routledge.

Newfield, D., \& Bozalek, V. (2019). A /thebuwa hauntology, from silence to speech: Reconfiguring literacy practices. In C.R. Kuby, K. Spector, \& J.J. Thiel (Eds.), Posthumanism and literacy education: Knowing / Becoming / Doing literacies (pp. 37-54). Routledge.

Rowsell, J., \& Burgess, J. (2017). Around and around we go: Layering turns into the multiliteracies framework. In F. Serafini and E. Gee (Eds.), Remixing multiliteracies: Theory and practice from New London to new times (pp. 74-90). Teachers College Press.

Smythe, S., Hill, C., MacDonald, M., Dagenais, D., Sinclair, N., \& Toohey, K. (2017). Cambridge University Press.

Srivastava, P., \& Hopwood, N. (2009). A practical iterative framework for qualitative data analysis. International Journal of Qualitative Methods, 8(1), 76-84.

Social Sciences and Humanities Research Council. (2018). The next generation of emerging global challenges. Policy Horizons Canada.

Stegelin, D. A. (2003). Application of the Reggio Emilia approach to early childhood science curriculum. Early Childhood Education Journal, 30(3), 163-169.

Tal, C. (2014). Introduction of an emergent curriculum and an inclusive pedagogy in a traditional setting in Israel: A case study. International Journal of Early Years Education, 22(2), 141-155.

The New London Group. (1996). A pedagogy of multiliteracies: Designing social futures. Harvard Educational Review, 66(1), 60-92.

Thomas, N. (2008). Small boxes, big sounds: Spontaneous music in kindergarten. In C. A. Wien (Ed.), Emergent curriculum in the primary classroom: Interpreting the Reggio Emilia approach in school (pp. 19-25). Teachers College Press.

Toohey, K., Dagenais, D., Fodor, A., Hof, L., Nuñez, O., Singh, A., \& Schulze, L. (2015). "That sounds so cool": Entanglements of children, digital tools, and literacy practices. TESOL, 49(3), 461-485.

UNESCO (2017, January 31). E2030: Education and skills for the 21st century.

Verwys, S. K. (2007). "Teacher, teacher, tell us about the brain!" Sharing decision making about curriculum in preschool. YC Young Children, 62(4), 97-100.

Wiebe, S., \& Caseley Smith, C. (2016). A/r/tography and teacher education in the 21st century. McGill Journal of Education, 51(3), 1163-1178. http://doi.org/10.7202/1039633ar

Zhang, Z., \& Heydon, R. (2014). Lived literacy curriculum in a globalized schooling context: A case study of a Sino-Canadian transnational programme. Journal of Curriculum Studies, 46(3), 389-418. http://doi.org/10.1080/00220272.2013.878395

Zhang, Z. (2015). Chinese and Canadian teachers implement a hybrid Sino-Canadian curriculum: A multiliteracies perspective. Teaching and Teacher Education, 48(2015), 106-116. http://doi.org/ 10.1016/j.tate.2015.02.006

Zhang, Z., Heydon, R., Li, W., \& Malins, P. (2020). Literacies and identities in transnational education: A case study of literacy curricula in a Canadian transnational education program in China. Curriculum Journal, 31(1). http://doi.org/10.1002/curj.5 
ZHENG ZHANG is an Associate Professor at Faculty of Education, Western University, London, Ontario, Canada. Her research interests include literacy and biliteracy education and curriculum studies of international and transnational education. zzhan58@uwo.ca

WANJING LI is a $\mathrm{PhD}$ Candidate at the Faculty of Education, Western University, London, Ontario, Canada. Her research interests span curriculum studies, literacies, bilingualism, biliteracy, teacher education, and international and transnational education undergirded by multiliteracies, particularly transnational curricula in culturally and linguistically diverse school settings.wli466@uwo.ca

ZHENG ZHANG est professeur agrégé à la Faculté d'éducation de l'université Western, London, Ontario, Canada. Ses intérêts de recherche comprennent la littératie, la bilittératie et les études curriculaires de l'éducation internationale et transnationale.zzhan58@uwo.ca

WANJING LI est une candidate au doctorat à la Faculté d'éducation de l'université Western, London, Ontario, Canada. Ses intérêts de recherche couvrent les études curriculaires, les littératies, le bilinguisme, la bilittératie, la formation des enseignants et l'éducation internationale et transnationale sous-tendue par les multilittératies, en particulier par les programmes d'études transnationaux dans des contextes scolaires culturellement et linguistiquement diversifiés.wli466@uwo.ca 